\title{
Urban Health and Happiness in Hutongs and Highrises
}

\begin{abstract}
SUMMARY
Urban bodies are complex integrated adjustable systems (CIAS), in flexible interaction with their natural, cultural, economic and political biotopes. Small entangled communities such as hutongs, existing in China for over 1000 years, and modern high-rise apartment buildings to a different extent represent more or less healthy and stable communities, based on interpersonal and interfamilial interaction, trust and solidarity, shared interest and involvement in sports, arts, gardening, social and other activities. Urban and other communities are interconnected by common history, narratives and visions, religions and internet cyberspaces. Religions and new internet communities extend beyond the local communities of hutongs, apartment buildings, cities and businesses; they may support or threaten local urban community and coherence.
\end{abstract}

Keywords: biotope, cyberspace, geospace, groupiness, happiness, hutong, highrise, urban health.

\section{Urban Settlements and Ways of Walking}

Gabriel Marcel' ${ }^{1}$ defined our human species as 'homo viator' (1949), always on the way to new lands and shores, unsatisfied with what was achieved and always hoping for more and better, now even integrating robots and cybots for work and companionship into our already highly cultivated technological and economic human biotopes. It seems that social connectedness rather than theoretical correctness establishes peace and happiness in settlements of all kinds and that agricultural and

\footnotetext{
* Correspondence Address: Institute of Philosophy, Ruhr University, Bochum, Federa Republic of Germany I Kennedy Institute, Georgetown University, Washington DC, United States of America / Renmin University, Beijing, People's Republic of China. E-mail: Sasshm@aol.com.

1 Marcel, Gabriel (1945). Homo Viator, Paris: Aubier.
} 
other technology provided better and safer settlements than nomadic lifestyle ${ }^{2}$. But different to other species such as ants and bees, we humans seem to be biologically imperfect for good and stable integration, neither in original jungle biotopes nor in those many different ones which we built and still are expanding, escalating, altering, sometimes for the good and sometimes for the bad. We sometimes build smart and even happy and healthy communities, sometimes we destroy peoples, biotopes, public and private spaces intentionally or by mistake and negligence on our neverending walks and ways. We have experimented kingdoms, democracies, anarchies, and dictatorships of various kind, also with integrating and separation of the sexes, races, and religions of the people.

Politics is mostly measured and influenced by Gross National Product, GNP - a more accurate measurement may be the Gross Happiness Product, GHP, devised in 1972 by King Wangchuck of Bhutan and adopted by the United Nations in 2012. The Bhutan happiness measurement has not yet at all been used to direct public awareness and political discussions to improve individual people, families, clans, villages, and ecosystems are more treasured than the economic richness of communities. For example, in 2015, 8.4\% of people were deeply happy, $37 \%$ extensible happy, 47.9 $\%$ narrowly happy, $8.8 \%$ unhappy; this was an improvement of $1.8 \%$ over the Bhutan figure of 2010. The actual five-year plan contains detailed goals or industry, education, trade, renewable energies, health, ecosystems, governance, vulnerable populations ${ }^{3}$.

In cultivating raw lands in meadows and crop fields, building houses, and wearing clothes to adjust to various climates, we developed tools and weapons to cultivate nature into civilization and to defend against animal and human aggressors. But unfortunately, we humans also killed ecosystems, animals, and humans in order to survive, by poor calculation or by immoral intend. Nomadic life ended whenever the opportunities for settling-down become real and attractive. Thus, it was the 'homo viator' biology, which caused us, humans, individually and collectively to not be content with achieved levels of engineering, socialization, cultivation, and transformation.

\section{Healthy Communities in Sustainable Political Bodies}

Urban cultures experimented with various kinds of settlements for clans, families, and social ecosystems. One of the earliest and most stable types were traditional

2 Sass, Hans-Martin (2016). Cultures in Bioethics, Zürich: Lit Verlag, 52.

3 Sass, Hans-Martin (2016). Cultures in Bioethics, Zürich: Lit Verlag, $231 \mathrm{f}$. 
hutongs surrounded by a wall and containing small communities with private, public, and semi-public space that for centuries have been the geographical body for families and communities. Hutongs have different names given by their inhabitants. Some have mythological names or are named in honor of kings. Individual hutongs have different stories about their neighbors, events, and festival, which make them different from others. Inhabitants from neighboring hutongs have to be invited to enter and rarely are allowed to stay overnight. I once went with a friend on a bicycle tour in an old section of Beijing and saw many people in front of a hutong celebrating a wedding; the friendly people invited both of us to join them for a wine and dancing in the center of the hutong, but then we realized that a little less than one hour was enough and everyone said 'good-bye, ni hou'. The plurality of different social ecosystems and traditions seems to be stable and healthy for these hutong neighborhoods, even in the future of city development.

Modern high-rise buildings provide no semi-public or public spaces, only warehouselike separated apartments for private use. This architectural situation stands in contrast to traditional culture and the human need for solidarity, friendship, and neighborhood. Cultures and values of propriety, honesty, justice, and honor are built in real geography among real people, real families, real communities. Additionally, the loss of a close geographic relationship might increase the emigration of people from geo-spaces to cyber-spaces. Non-geographical spaces such as religions have always existed and had both positive and negative influences on real geographic solidarity and community culture. This is increased today by new cyberspace territories such as social or interactive websites and may have even stronger positive or negative influence on peace and harmony, even dysfunction of territorial and social communities, including social and family disintegrations, rebellions, and terror at local and global levels.

Old Taoist wisdom reminds us of the importance of diversity and coherence for the health and happiness of political bodies: 'Rule the land with justice, fight a war with surprise, and win a country with harmonious action (wuwei). How do I know that this? - The more prohibitions we have, the more rebellious the people will be. The sharper the weapons are under the people, the more turbulent the land will be. The shrewder the people, the more abnormal things occur. The more laws there are, the more thieves and robbers will be there. Therefore, the wise person says: When I am not greedy, the people will become rich by themselves. When I act with harmony, people will change by themselves. When I refrain from imposing, the people will do justice by themselves. When I refrain from craving, the people will also get rid of their cravings'. ${ }^{4}$ - Ruiping Fan of Hongkong University addresses the

4 Lao Zi, Guodian text: B 29-32; Dao te Ching 57. 
classical Chinese family concept in differentiating nonegalitarian gradual forms of connectedness in social bodies and ecosystems. Fan reminds us that cultural, social, and political interconnectedness in the Confucian sense does not mean equal, but rather differentiated and graded connectedness:'1. One has more moral obligation to take care of one's family members (such as one's parents, spouse, and children) than others in one's local or religious community (such as neighbors, friends, and acquaintances); 2. One has more moral obligation to take care of those in one's local or religious community than other citizens in the state; and 3. One has more moral obligation to take care of one's fellow citizens in the state than other people in other states'. But Fan adds for a future contact with extraterrestrials also a 4th suggestion: 'one has more moral obligation to take care of one's fellow humans on earth than for extraterrestrial aliens', p. 2145. - A Human Freedom Index (HFI), published jointly by the Cato Institute, the Frazer Institute, and the Friedrich Ebert Foundation, measured personal, civil and economic freedom with Hong Kong, Switzerland, Finland, Denmark, the first four and Saudi Arabia, Venezuela, Zimbabwe, Iran among the

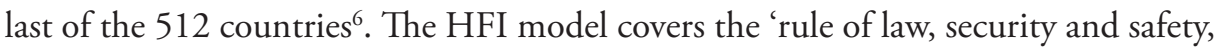
movement, religion, civil society, expression, relationships, size of government, legal system and property rights, access to sound money, freedom to trade internationally, regulation of credit, labor and business'.

Long-lasting states and societies seem to have a rather modular body of more or less loosely integrated or interacting parts, which allowed for transformations and modifications once one or the other part became weak, distressed, sclerotic, cancerous, or otherwise threatening the others or the entire body. Vast political bodies with relatively long lives were not run on a short dominant leash; the empire of Dschingis Khan was a center over multiple more or less independent bodies enjoying the freedom of religion and internal affairs; Charlemagne run his European empire with only a few hundred people at the center, among them a few dozen riding messengers carrying mail to his various relatively independent fortresses; the more successful emperors of China ruled the provinces and instructed the mandarins by royal letters and only in most dangerous situations had to seek solutions and protect the body politics by war. The multi-centered 1000 years of the Holy Roman Empire ${ }^{7}$ were marked by various interacting power bodies of kings, princes, dukes, bishops, and free cities in a decentralized manner, also by relatively autonomous rural peasant

5 Fan, Ruiping (2016), Nonegalitarian Social Responsibilities for Health, Kennedy Inst of Ethics J, 26(2), 204, 214.

6 Vasquez, Ian, Porčnik, Tanja, eds., (2015). The Human Freedom Index. Global Measurement of Personal, Civil and Economic Freedom, US: Cato-Fraser-Liberales. Available at: https://www.cato.org/sites/cato.org/files/humanfreedom-index-files/human-freedom-index-2015.pdf

7 Wilson, Peter H. (2016). The Holy Roman Empire. A 1000 Years of Europe's History, UK: Penguin. 
communes owning most lands and having their own rules and traditions on how to work the lands together as a commune or allocate to certain families. For millennia, important settlements were protected by walls; rivers were the connecting roads of choice; capitals and rulers quite often were far away. Today, I can fly in eight or ten hours from Beijing or New Delhi to capitals as brains and wills of political bodies in Europe, the Americas and, of course, in Asia. Today, I can travel from Beijing to Shanghai by comfortable rapid train in four hours, in about the same time from Paris to London. How much longer than four months each way would Confucius have needed by ox wagon or donkey to travel from his family place close to Jinan, Shandong Province, which is halfway between Beijing and Shanghai to either one of these cities; how long did it take to get messages by riding messengers or sailboats from Paris to London or New York before telegraph cables were laid 150 years ago? ${ }^{\text {? }}$ Today, I can reach nearly every marketplace and person in no-time via internet and skype around the clock. How will our social and political bodies change and adapt to those new territories?

The actual corona pandemic that threatens all interconnected individuals and urban bodies around the globe is but one among half a dozen special threats to our integrated social and political bodies in the $21^{\text {st }}$ century: (1) Biological risk via natural or manmade pandemics, antibiotic-resistant microbes, the disappearance of species (bees, etc.) essential for the health of integrated bios. (2) Destruction or manipulation of our electric roots via natural or man-made EMP (Electric Magnetic Pulse), software manipulation in utilities, corporations, states; (3) revolts and repressions by individual instigators and internet communities, by fake information from states and corporations; (4) loss of trust in not well understood complicated interactions of geoworlds and cyber-worlds, manipulations by elites in states and non-states, resulting in withdraws into 'safe' localism and extremism; (5) risk of territorial mix-up: new cyberspace communities provide incentives and rewards which are not found in geospacer; (6) loss of control, as individuals feel overpowered by complexities in the economy, artificial intelligence, and complex and not well-understood interactions. ${ }^{?}$

\section{Diversity and Complexity in Support of Healthy Urban Bodies}

I can summarize the Taoist wisdom about the sustainable health of urban bodies in 10 characteristics of diverse and healthy urban bodies:

8 Sass, Hans-Martin (2014), An Early Hegelian Vision of the Internet. Ernst Kapp's 1845 Philosophy of Cultivating Space and Time, Jahrbuch für Hegelforschung. St Augustin: Academia, 15/17,11-34.

9 Sass, H.-M. (2016), 205-246. 
1. Social Bodies: Social communities as living bodies have a long or short life expectancy, they 'want' to be happy. The body or certain organs may suffer disease, inflammation, or confusion; they are dangerous to the integrated social and political bodies as they are to individuals and natural biotopes.

2. Integrated Health Care: Good care for social and political bodies is as important for social, cultural, economic, and political integrated bodies and organs as it is for individuals.

3. Buildings: High-rises must include public and semi-public spaces, such as meeting rooms for diverse groups and activities such as card playing, needle craft, movie watching, tea time company, book clubs, social support, teenager or elderly meetings. Individual high-rises should have individual names or resemble symbols; lobby halls and public spaces should have paintings, calligraphs, seating corners, exercise rooms, or even a swimming pool.

4. Community Environment: should include 'meeting' places such as small shops, restaurants, kids' playgrounds, sports facilities [in and between buildings], jogging trails, sitting areas and parklike greens; whenever possible also small private garden communities with small individual vegetable plots. The community environment needs to include and support nature, lifestyles, easy shopping and communicating, various fun activities, and networks of mutual support and friendship.

5. Local Culture: local cultures and traditions need to be created to give people and families a feeling of 'belonging' and pride, such as narratives of local mythological dragons and heroes, local political events and monuments, stories about princes and princesses, local movie stars, exemplary farmers, mothers, war heroes need to be found and re-narrated [even invented, if missing]. - Traditional national festivities and those related to the seasons, but also new local festivities related to local dragons, temples and monuments, memorable local hero festivals, local sightseeing attractions will bring people of different professions and education together as neighbors forming strong local bonds and stable friendship and community.

6. Geo-space and Cyber-space: Traditional religions, narratives, fashions had both positive and negative influences on social culture, peace, stability, and happiness; new cyberspace communities can and will have similar and maybe even stronger impact on health and happiness of individuals and communities; therefore strong geographical roots based in the neighborhood, friendship, family, hobbies, and leisure time activities will be the best way to integrate positive cyberspace influences and reject negative or even destructive and terrorist influences from 'outside'. Unfavorable or extreme positions should be fought in open discourse and not be suppressed into 'underground caves'. 
7. Integrated Diversity: Clubs bring people of different backgrounds together in sports, hobbies. Social engagement should be initiated and sponsored to build a diverse and stable community of happy people; happiness will count more than money; individual volunteer citizens will become famous and be honored by the people and local leadership.

8. New Communities: Villages in rural areas traditionally provided for family life in small trust-and-culture related neighborhoods with semi-public and public areas. Modern high-rise buildings have no or minimal semi-public or public spaces, only warehouse-like separated apartments for private use. Often, the architectural situation is in stark contrast to traditional culture, biopolitical nature, and the human need for solidarity, friendship, and neighborhood. - Cultures and values of propriety, honesty, justice, and honor are built in real geography among real people, real families, real communities. Additionally, the loss of a close geographic relationship might increase frustration, antisocial behavior, and emigration from geo-spaces to cyber-spaces.

9. Geospace versus Cyberspace: New cyberspace territories and interactive websites might have similarly strong positive or negative influences on peace and harmony, even dysfunction of territorial social communities, social and family disintegrations, rebellions, and the possibility of local and global terror. Leaders and citizens thus must build cultures and communities in new urban territories. Individuals, families, clubs, companies, communities, societies are complex, highly adaptable biological systems 'longing' for success, health, good integration, stability, and long and healthy lives.

10. Responsible Leadership: Head and Heart of integrated social bodies - political parties, corporations, people - need to engage together in making and keeping the communal social body and its various and different organs happy, healthy, and stable for long life, - in cultivated natural and social biotopes. Leadership is of essential lifesaving importance, in particular for new political and social bodies due to the many technological, economic, cultural changes locally and globally in the $21^{\text {st }}$ century.

The Taoist wisdom is shared by none other than the religious Rabbi and enlightened philosopher Moses Mendelsohn, who in 1819 discussed intolerance and religious fighting: 'Brethren, if you want true peacefulness in God, let us not lie about consensus when plurality seemed to have been the plan and the goal of providence. No one among us reasons and feels precisely the same way the fellow human does. Why do we hide from each other in masquerades in the most important issues of our lives, as God not without reason has given each of us his/her own image and face'? ${ }^{10}$ - Given the quest for harmony and the diverse and often contrarian powers within

10 Mendelsohn, Moses (1819). Jerusalem oder über religiöse Macht und Judentum, Ofen: Burian, 201. 
social, cultural and political bodies, we may we rephrase Mendelsohn's insight into the diverse bios of individual humans and human communities into a bioethical and biopolitical for political bodies and urban biotopes: Brethren, citizens, politicians, and leaders, if you want peace and harmony in our political life, then let us not lie about uniformity when adaptability, plurality, and modality seems to have been the blueprint in the wisdom of bios. No one among the political bodies has a fully identical bodily structure and social interactions as compared to the others. Why do we hide from each other behind the masquerades of one-size-fits-all democracies or similar bodies, as the vital, highly adaptable and complex human bios has not without reason given us and our political bodies different shapes and shades?

\section{Thomas Hobbes and Abraham Bosse's Vision of Pluriperspective and Pluripotent Bodies}

Thomas Hobbes in his 'Leviathan' describes the healthy social and political community as a body, alike bodies of animals and humans; Abraham Bosse in the title page of the 1651 German edition presents an engraving of the biological, bioethics, biosocial and biopolitical power of the oversized political body, waving the sword in one hand and a ruler's crosier in the other, his large body formed by a diverse number of faces and people, surrounded by images of houses, castles, tanks, farms, and diverse meeting places. ${ }^{11}$

Modern societies are symbiotic complex and adoptable living beings of natural persons, natural communities such as families, clans and villages or neighborhoods, and economic and legal persons such as enterprises, institutions, bureaucracies, and similar cyberspace based persons, communities, and powers. They all want to live well, to grow, and to sustain their lives and networks; this might lead to cooperation and support, network building, favoritism, mutual aid, and help, also to corruption and exploitation in the interest of survival and protecting and even expanding one's biotope and influence. These tendencies of different players can and do lead to dysfunctional bodies and biotopes ${ }^{12}$. Other species exist in the same geographical spaces as we humans, but they recognize their and our worlds differently; bios is pluripotent and pluriperspective life all the time.

11 Hobbes, Thomas (1651). Leviathan or the Matter, Forme and Power of a Commonwealth Ecclesiastical and Civil, Hamburg.

12 Fukuyama, Francis (2014), The Sources of Political Dysfunction, Foreign Affairs Sept/Oct, 5-26. 


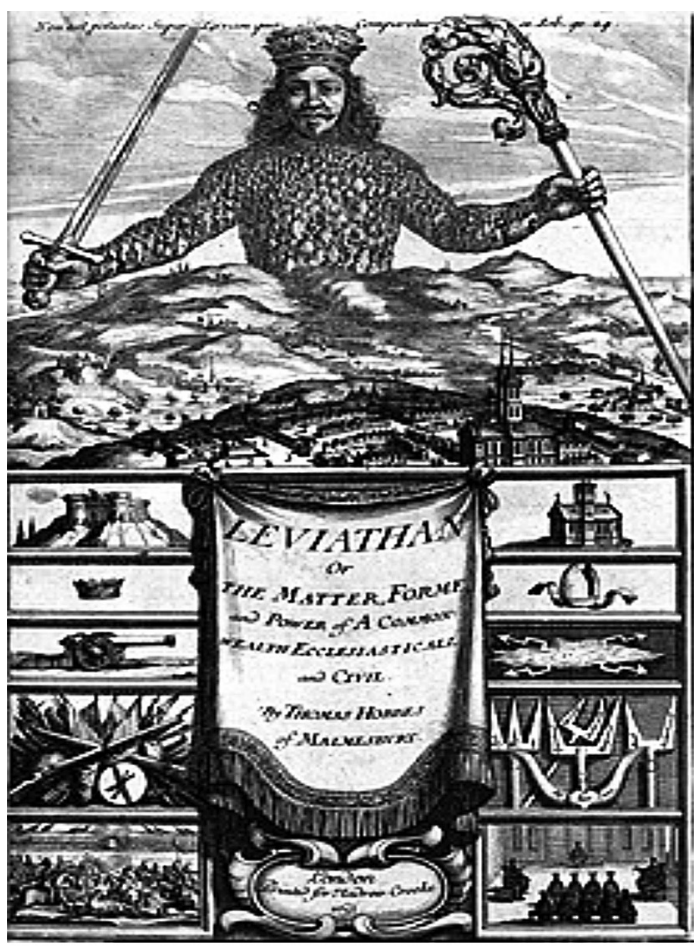

As far as our human species is concerned, it seems 'that the evolution of our species privileged group survival over personal survival' ${ }^{13}$. Bees live in complex and highly structured social and biological communities, but sometimes they suddenly abandon their hives, a phenomenon described as 'colony collapse disorder" ${ }^{\text {'4 }}$; humans on and off destroy their complex political, cultural, social, and economic communities as we these days in some Arab and Muslim countries and elsewhere in the world, a phenomenon that we may describe as 'culture collapse disorder', based on discontent, hate, extreme ideology, terror, exploitation, and just widespread unhappiness and the loss of mutual trust and mutual aid. In the coming age of globalization and the internet, national or regional states are going to share their integrating power and matter with other social, cultural, communal and political bodies, and loyalties of citizens might be divided not in traditional ways such as between church and nation state but in much more complicated and changing ways.

Individual bodies are more integrated as political ones; but political bodies may come in even more shapes and shades than individual bodies. Some body parts such as

13 Lawler, Peter A. (2013), Moderately socially conservative Darwinism, The New Atlantis 38, 155-162.

14 Lu, Chensheng, Warchol, Kenneth M., Callahan, Richard A. (2014), Sub-lethal exposure to neonicotinoids impaired honey bees winterization before proceeding to colony collapse disorder, Bulletin of Insectology 67(1), $125-130$. 
Mafiosi, dictators, and leaders of good or bad dominating economic, religious or social groups might be happy and healthy while the rest of the political and social body suffers, in disorder and sickness because of negligence or exploitation. Political bodies strive for the same $8 \mathrm{C}$ biological properties (communication, cooperation, competence, competition, contemplation, calculation, compassion, cultivation); they need internal and external communication and cooperation as their bloodstream and nervous system, competence and competition in survival, contemplation, and calculation in order to set their vision and goal into practice, compassion in dealing with their constituency, and good skills in cultivation for extending their lives into the future. - We also find the 3 F's - foods, funs, faiths - as good constituents for the long and happy lives of political bodies. Food in the form of foodstuffs, other materials for individual and collective living such as housing, police, military, and hospitals is the basis for living together. Fun and satisfaction are essential for harmony and happiness of the various cells and parts of the political body; it includes festivals, good entertainment, and good housing, symphony orchestras and libraries, radio and television, enjoyment in having friends and families and making babies. Faith may be religious faith, but in a wider sense faith and trust in solidarity and camaraderie, in equal or relatively equal civil and human rights, in the sustainability and even improvement of existing social, political and cultivated biotopes, of course for some also faith in a higher order of harmony created and promised by Gods, a spiritual togetherness and brotherhood in human bios and culture, of the Dao or Mother Nature as all-encompassing bios.

\section{A Concluding Narrative: The Little Town by the River.}

Instead of a traditional conclusion, I will end with the multifaceted and pluripotent narrative I have used for many years in conferences and classroom teachings to illustrate the complexity and interactivity of urban bodies working together healthily and happily in tolerance and respect for each other while avoiding destruction and fight over ideological or religious visions for 'better' worlds. The 'river' symbolizes the ancient ways of fertilization, traffic, and control, nowadays by the increasing powers of internets of various sorts. The narrative is influenced by the Prophet's vision of a stable and healthy urban biotope when Mohamed had to escape from Mecca to Medina; he devised the 'Contract of Medina' with its 46 paragraphs, supporting harmony, culture, and economic success in a complex multicultural society. ${ }^{15}$

15 Hamidullah, Muhammad (1975). The First Written Constitution in the World, Lahore: Askrat Press, 3rd ed.; cf. Google: Wikipedia 'Constitution of Medina', and Sass, Hans-Martin (2016). Cultures in Bioethics, Zürich: Lit Verlag, 53-56 (Reprint with permission of Lit Publishers). 


\section{THE LITTLE TOWN BY THE RIVER}

This town is really small, measured by the long river and the surrounding hills small as a drop in the bucket. But it happens to be the only town beside the river and the people are proud of their town, the river stream, and their great wealth. This wealth they see in the dignity and nobleness of their citizens, their different city quarters, and their cultivated lands and waters. The freedom and security of the citizens are cherished above all. They help each other and lend a hand to the young generation to act responsibly, to respect 'others', even if they do not share their opinions or their absolute values. They loathe lies, theft, killing, injustice, egotism, arrogance, and intolerance. To lie, steal, and murder will be punished, even when thieves and murderers pretend to act in the name of God or out of a higher insight. They do not all believe in God; yet they all are of the opinion that, if there were a God, he would forbid to kill, steal, or lie. This is also expressed by those living in Jewish, Christian, and Muslim houses and streets of the 'Almighty and Merciful'. They who believe in God are also aware of the power of Satan; all know of the evil in Man and of evil persons against whom they feel obliged to fight. They detest intolerance and spare no effort to create a culture of communication and cooperation by listening and arguing based on trust.

Each of them has a special competence and competes with others in improving and protecting the common goods of their integrated city bios. Of course, they are free to contemplate about bios, biotopes, and creation in their own individual fashion, with or without networks of friends, and draw conclusions from their insights and intuitions in calculating their own position and the improvement of their service and integration within their town. Respect for each other and the entire world of bios surrounding them and compassion for each other, in particular for the weak, desperate, sick and needy are the basis of their harmony and their richness in valuables and values. Communication and cooperation, competence and competition, contemplation and calculation, compassion, and cultivation are the pillars on which their individual and collective culture is based and they are all aware that these $8 \mathrm{C}$ 's need to be protected and defended against evildoers from the inside and aggressors from the outside.

It is their opinion that human dignity finds expression mainly in respecting the dignity of the individual conscience. They honor the position of each fellow citizen with respect to their final religious or philosophical conviction as inviolable. Overall, they respect and request the individual's conscience responsibility; they do not accuse each other of immorality or being uncultured when their own judgment in matters of moral and culture differ from others. Even if they cannot accept the conviction of their fellow-citizens or regard them to be abstruse, they will do everything that 
these fellow-humans will not be forced to do and act against their conviction and conscience. For example, foods are labeled as to signify whether they are kosher, vegetarian, or organically grown. Nobody is forced to take medication or abort unborn life, to donate or accept organs or to take on work that violates personal values and religious or humanist beliefs. Whenever someone proposes to put pressure on the conscience of others, they all turn very angry because thereby they see a violation of the dignity of the little town and the wealth of values of their citizens and communities. Most city laws contain a 'sunset clause' that indicates that law will use its force after a specific number of years, unless it has been extended or modified; they also include a 'conscience clause', that allows citizens to request an exemption on the grounds of conscience as long as this is possible without bringing harm to others.

The citizens of this town live in harmony with their natural biotopes and the many other forms of bios, which they have cultivated with microbes, plants, animals, colonies, and which they respect as 'brothers and sisters' within and around the bios of their city. They take great pride in having their own healthy personal microbiome and in creating probiotic biotopes in their houses, schools, offices, factories, assembly halls, parks, and agricultures. They enjoy reaching out to other people and cities, making prudent use of their $8 \mathrm{C}$ properties all the way around the globe by the waterways of their stream, by roads and airways, by digital networks of commerce and manufacturing, by communication and cooperation in social networks, by finding friends and partners, cultivating friendships and partnerships just as they do in their geographical locality.

A look at the architecture of the houses provides a clear view of the cultural and ethical structure of this city at the water. As different as they appear, these houses are built on the $8 \mathrm{C}$ pillars in the basement and the first floors, which are connected for the purpose of security of the inhabitants and the city as a whole against hunger, murder, torture, and for the care and sake of all who cannot help themselves. However, the layout and the furnishing in the upper floors show the rich variety of values and visions of their owners and inhabitants. There are debates in one of the houses whether or not a human fetus has a personal moral or legal right or is to be seen as a part of the body of the mother and the personal dignity of the pregnant person. In another house, we hear debates about whether religious rules for fasting may be broken in case of illness in order to give medicine and nutrition to patients. The century-old debate about the question whether a terminally ill hoping for life after death should ask for the 'poisoned drink' has currently been toned down; but there are adamant calls that physicians make better use of palliative medicine in easing pain and suffering and thus making euthanasia discussions and ensuing abuse unnecessary. On the rooftops, we hear the loudest and most exhaustive and 
sometimes crazy debates, arguing those very complex questions, whether God is one person in three or three in one or a person at all, whether there is one main prophet or even a representative of God on earth, whether all things in nature are divine and require adequate respect or not, whether there are invisible spirits or demons, and whether they have power over us or the world of bios. Furthermore, whether human zygotes ensouled and may be resurrected in paradise or take part in the process of reincarnation? Do individual souls transmigrate, do animals or plants have souls, do transgenic animals, having human DNA, therefore also have a part of a human soul or spirit? Does one have to believe in higher spiritual authority in order to be a decent person and a good fellow-citizen?

Debates like these have gone on for a long time and most likely will never stop. In their own way, these quarrels represent the great richness of values and visions of this little town by the river. In some of the houses, people are sympathetic to such eccentric palaver, others are not and sometimes judge it as silly, absurd, and not necessary for being a valued member of the city community. Some are of the opinion that these are things that are 'divine secrets' and, as such, call for modesty rather than righteousness. Nevertheless, everyone would go out of the way to secure the right of convincing, discourse, quarrel, and dissent to the disputing parties. There is an awareness and appreciation that reasoning in the upper floors does influence the deeds on the lower ones and rightly so, as long as fellow humans are respected and supported and not hurt or belittled. But they do not accept when individuals or clans violate the rules of civility in the community. Whoever does not like those local rules and ways of life will be free to move somewhere else, and it goes without saying that as long as people live in the village as citizens or guests, they have to respect these rules of mutual respect and the dignity of their fellow humans.

The names of the streets and plazas remind the citizens of their common history and the roots of the town's culture. One of the squares is dedicated to the victims of murder, violence, and terrorism, to the slain burned residents of Jericho and Ai, Nanjing, and Dresden, the victims of innumerable pogroms of Jews, the tortured and burned of the so-called Holy Inquisition, the rape of Nanjing, and the victims of global terrorism such as on the World Trade Center in New York City. Houses of Contemplation have murals representing the integrated and integrating harmony of the bios of the city and its surroundings. 


\section{References}

"Constitution of Medina" in: Wikipedia, the Free Encyclopedia, https://en.wikipedia.org/wiki/Constitution_ of_Medina (accessed: 30 March 2020).

Fan, Ruiping (2016), Nonegalitarian Social Responsibilities for Health, Kennedy Inst of Ethics J, 26(2), 204, 214.

Fukuyama, Francis (2014), The Sources of Political Dysfunction, Foreign Affairs Sept/Oct, 5-26.

Hamidullah, Muhammad (1975). The first written Constitution in the World, Lahore: Askrat Press, 3rd ed.

Hobbes, Thomas (1651), Leviathan, or the Matter, Form and Power of a Commonwealth Ecclesiastical and Civil, Hamburg.

Lao Zi, Guodian text: B 29-32; Dao te Ching 57.

Lawler, Peter A. (2013), Moderately socially conservative Darwinism, The New Atlantis 38, 155-162.

Lu, Chensheng; Warchol, Kenneth M. and Callahan, Richard A. (2014), Sub-lethal exposure to neonicotinoids impaired honey bees winterization before proceeding to colony collapse disorder, Bulletin of Insectology 67(1), 125-130.

Marcel, Gabriel (1945), Homo Viator, Paris: Aubier.

Mendelsohn, Moses (1819), Jerusalem oder über religiöse Macht und Judentum, Ofen: Burian, 201.

Sass, Hans-Martin (2014), An Early Hegelian Vision of the Internet. Ernst Kapp's 1845 Philosophy of Cultivating Space and Time, Jahrbuch für Hegelforschung. St Augustin: Academia, 15/17, 11-34.

Sass, Hans-Martin (2016), Cultures in Bioethics, Zürich: Lit Verlag.

Vasquez, Ian and Porčnik, Tanja, eds., (2015), The Human Freedom Index. Global Measurement of Personal, Civil and Economic Freedom, US: Cato-Fraser-Liberales, https://www.cato.org/sites/cato.org/files/ human-freedom-index-files/human-freedom-index-2015.pdf

Wilson, Peter H. (2016), The Holy Roman Empire. A 1000 Years of Europe's History, UK: Penguin.

\section{Urbano zdravlje i sreća u hutonzima i neboderima}

\section{SAŽETAK}

Urbana tijela su složeni integrirani prilagodljivi sustavi (CIAS) u fleksibilnoj interakciji sa svojim prirodnim, kulturnim, ekonomskim i političkim biotopima. Male prepletene zajednice, poput hutonga, koje u Kini postoje više od 1000 godina, i moderne visoke zgrade sa stanovima, u različitoj mjeri predstavljaju više ili manje zdrave i stabilne zajednice, utemeljene na međuljudskoj i međuobiteljskoj interakciji, povjerenju i solidarnosti, zajedničkom interesu i uključenosti u sportove, umjetnost, vrtlarstvo, društvene i druge aktivnosti. Urbane i druge zajednice međusobno su povezane zajedničkom poviješću, narativima i vizijama, religijama i internetskim cyberprostorima. Religije i nove internetske zajednice protežu se izvan lokalnih zajednica hutonga, stambenih zgrada, gradova i tvrtki; one mogu podržavati ili ugrožavati lokalnu urbanu zajednicu i koherenciju.

Ključne riječi: biotop, cyberspace, geoprostor, grupnost, sreća, hutong, neboder, urbano zdravlje. 